\title{
Limitasi Penggunaan Surat Kuasa Penjualan dan Pemasaran Suka Rela Objek Jaminan Dalam Kredit Perbankan
}

\author{
Rizkia Aisyah Nur \\ aisyahrizkia98@gmail.com \\ Universitas Airlangga
}

\begin{abstract}
The power of attorney is made in an authentic deed or underhand deed, underhand deed is a document made by the parties without the existence and interference of the general official and the legislation does not require it, in relation to the power of attorney, then the authority in making the authentic deed is a notary public. The formulation of the problem in this study is whether the selling power of attorney and voluntary marketing of the object of mortgage agreed by the customer with the bank is permitted by legislation and is there any restriction of authority in the use of the sales authorization letter by the bank? The approach used in this study is the statutory approach and the conceptual approach. This research uses several primary legal materials which include provisions relating to the subject matter and secondary form of journals relating to the subject matter. In accordance with his position in the eyes of the law, then if the Mortgage has been submitted, the execution of the authority to use the power of attorney to sell and market voluntarily cannot be used. Therefore, in making the power of attorney to sell and market voluntarily it should not be absolute, therefore the use of the power of attorney to sell and market voluntary is actually not important because there is an agency guarantee material that guarantees the execution of collateral.

Keywords: Limitation of Power of Attorney for Sale; Voluntary Marketing of Collateral Objects; Banking Credit Agreement.
\end{abstract}

\section{Abstrak}

Surat kuasa dibuat secara akta otentik maupun akta dibawah tangan, akta dibawah tangan adalah dokumen yang dibuat oleh para pihak tanpa adanya keberadaan dan campur tangan dari pejabat umum serta peraturan perundang-undangan tidak mengharuskannya, dalam kaitannya dengan surat kuasa maka yang berwenang dalam membuat akta otentiknya adalah notaris. Perumusan masalah dalam penelitian ini adalah apakah surat kuasa jual dan memasarkan sukarela atas objek hak tanggungan yang disepakati oleh nasabah dengan pihak bank diperbolehkan oleh peraturan perundang-undangan dan apakah terdapat pembatasan kewenangan dalam penggunaan surat kuasa jual oleh bank ?. Pendekatan yang digunakan dalam penelitian ini adalah pendekatan perundang-undangan (statute approach) dan pendekatan konseptual (conseptual approach). penelitian ini menggunakan beberapa bahan hukum primer yang meliputi ketentuan-ketentuan yang berkaitan dengan pokok bahasan serta sekunder berupa jurnal yang berkaitan dengan pokok pembahasan. Sesuai dengan kedudukannya di mata hukum, maka apabila Hak Tanggungannya sudah diajukan eksekusi kewenangan penggunaan surat kuasa menjual dan memasarkan sukarela tidak dapat digunakan. oleh karena itu dalam pembuatan surat kuasa jual dan memasarkan sukarela hendaknya tidak bersifat mutlak, maka dari itu penggunaan surat kuasa jual dan memasarkan sukarela sebenarnya tidaklah penting karena telah ada lembaga jaminan kebendaan yang menjamin eksekusi dari agunan.

Kata Kunci: Pembatasan Surat Kuasa Jual; Pemasaran Suka Rela Objek Jaminan; Perjanjian Kredit Perbankan. 


\section{Pendahuluan}

Kecenderungan masyarakat untuk mendapatkan modal atau dana dari bank di era ini semakin meningkat. Penyaluran kebutuhan modal oleh bank kepada masyarakat ini, disebut dengan istilah kredit atau pembiayaan. Menurut Pasal 1 angka 11 Undang-Undang Nomor 10 Tahun 1998 Tentang Perubahan Atas Undang-Undang Nomor 7 Tahun 1992 Tentang Perbankan yang selanjutnya akan disebut dengan UU Perbankan “Kredit adalah penyediaan uang atau tagihan yang dapat dipersamakan dengan itu, berdasarkan persetujuan atau kesepakatan pinjam-meminjam antara bank dengan pihak lain yang mewajibkan pihak peminjam untuk melunasi utangnya setelah jangka waktu tertentu dengan pemberian bunga".

Dalam UU Perbankan sebenarnya tidak dikenal istilah perjanjian kredit, tetapi tercantum kata-kata persetujuan atau kesepakatan pinjam-meminjam. Kata-kata tersebut menegaskan bahwa perjanjian kredit merupakan hubungan kontraktual yang berbentuk pinjam meminjam. Perjanjian kredit meskipun merupakan perjanjian yang akarnya adalah perjanjian pinjam meminjam, tetapi perjanjian kredit berbeda dengan perjanjian pinjam meminjam yang tercantum dalam Pasal 1754 Burgerlijk Wetboek yang selanjutnya akan disebut BW. ${ }^{1}$ Dalam perjanjian kredit tujuan penggunaan kreditnya telah ditentukan, pemberi kredit dalam perjanjian kredit juga telah ditentukan bahwa pemberi kredit adalah bank atau lembaga pembiayaan dan tidak dimungkinkan diberikan oleh individu, pada perjanjian kredit juga telah ditentukan bahwa uang pinjamannya harus dikembalikan beserta bunga, imbalan atau pembagian hasil. Lain halnya dengan perjanjian pinjam meminjam, dimana tidak diperjanjikan mengenai penggunaan uang yang dipinjam oleh debitur, pemberian pinjaman juga dapat dilakukan oleh individu, dan pengembalian pinjaman hanya beserta bunga yang hanya ada apabila diperjanjikan.

Kondisi ekonomi suatu negara sangat mempengaruhi para pengusaha baik Usaha Mikro, Usaha Kecil, Usaha Menengah atau sering disebut UMKM, maupun

${ }^{1}$ Admin, 'Mengenal Perjanjian Credit', (2019) <www.ercolaw> accessed 19 Agustus 2019. 
Usaha Korporasi. Hal ini sangat berdampak bagi perkembangan atau pertumbuhan Perbankan di Indonesia, karena dengan menurunnya kinerja nasabah debitor akan berdampak pada keterlambatan pembayaran kewajibannya kepada Bank atau terjadi penurunan kolektibilitas kredit dan apabila berkelanjutan akan menjadikan nasabah debitur dimaksud menjadi macet. ${ }^{2}$

Mengenai jaminan, jaminan pemberian kredit hakikatnya berfungsi untuk menjamin kepastian akan pelunasan utang debitur apabila nantinya debitur wanprestasi atau dinyatakan pailit. Hal ini dikarenakan tidak semua nasabah yang mendapatkan kredit dari bank dapat menggunakan dananya dengan baik dan benar. ${ }^{3}$ Oleh sebab itu, diperlukan adanya jaminan pemberian kredit tersebut untuk memberikan jaminan perlindungan bagi keamanan dan kepastian hukum kreditor yang dalam hal ini adalah pihak bank bahwa kreditnya akan tetap kembali meskipun nasabah debiturnya wanprestasi atau pailit, yakni dengan cara mengeksekusi objek jaminan kredit bank yang bersangkutan. Secara umum jaminan khusus terbagi dua, yaitu jaminan perseorangan dan jaminan kebendaan. Selain itu, dibuat juga surat kuasa menjual dan memasarkan secara sukarela yang selanjutnya akan disebut surat kuasa jual antara bank dengan nasabah debitur dan penerima kuasa, untuk melakukan transaksi jual beli, termasuk perbuatanperbuatan yang dibutuhkan dalam melakukan transaksi jual beli tersebut.

Surat kuasa jual, merupakan surat kuasa yang telah disiapkan oleh bank disetiap pemberian fasilitas kredit kepada nasabah debitur. Bank berkeinginan surat kuasa jual dibuat dalam bentuk otentik akan tetapi, notaris tidak mau membuat surat kuasa jual karena beranggapan tidak diperlukan lagi, sebab sudah terdapat akta jaminan kebendaan yang telah memberikan kewenangan bagi bank untuk melakukan eksekusi objek jaminan bilamana debitur wanprestasi. Hal ini sejalan dengan isi Instruksi Menteri Dalam Negeri Nomor 14 Tahun 1982 Tentang Larangan Penggunaan Kuasa Mutlak Sebagai Pemindahan Hak Atas Tanah yang

\footnotetext{
2 Wawancara dengan Trijatski Aris Moelia, Commercial Manager Bank Panin Dubai Syariah Tbk., Kantor Pusat, 16 Agustus 2019.

3 Asriadi Zainuddin, 'Kedudukan Hukum Surat Kuasa Menjual terhadap Objek Jaminan yang Dibebani Hak Tanggungan (2017) 1 Jurnal Al-Himayah.[301].
} 
selanjutnya akan disebut SK MENDAGRI No. 14 Tahun 1982. Tidak hanya itu, larangan penggunaan surat kuasa juga dilarang dalam Peraturan Otoritas Jasa Keuangan Nomor 1 Tahun 2013 Tentang Perlindungan Konsumen Sektor Jasa Keuangan yang selanjutnya akan disebut POJK No. 1 Tahun 2013. Akan tetapi, bank berdalih bahwa dengan adanya surat kuasa jual akan memudahkan penjualan objek jaminan apabila dikemudian hari debitur wanprestasi.

\section{Keabsahan Surat Kuasa Jual dan Memasarkan Sukarela}

\section{Surat Kuasa Jual dan Memasarkan Sukarela}

Dalam aktivitas perbankan dikenal adanya surat kuasa jual. Surat kuasa umumnya didefinisikan sebagai surat yang isinya berupa pemberian kewenangan kepada pihak lain untuk melakukan perbuatan-perbuatan hukum untuk dan atas nama sang pemberi kuasa. Pengertian umum surat kuasa adalah surat yang berisi tentang pemberian kuasa kepada seseorang untuk mengurus sesuatu sedangkan pemberian kuasa adalah pemberian kewenangan kepada orang lain untuk melakukan perbuatan-perbuatan hukum atas nama si pemberi kuasa. ${ }^{4}$ Dalam kaitannya dengan surat kuasa maka yang berwenang dalam membuat akta otentiknya adalah notaris, lain halnya dengan Surat Kuasa Membebani Hak Tanggungan yang selanjutnya disebut SKMHT hanya dapat dibuat oleh Pejabat Pembuat Akta Tanah yang selanjutnya akan disebut PPAT. ${ }^{5}$ Akta otentik dan akta dibawah tangan memiliki perbedaan penting, yakni pada siapa pihak membuat akta tersebut. Akta otentik dibuat oleh atau dihadapan pejabat umum yang berwenang dalam hal ini notaris, sedangkan akta dibawah tangan dibuat sendiri oleh para pihak. ${ }^{6}$ Pasal 1870 BW menyatakan bahwa akta otentik memberikan suatu bukti yang sempurna atas apa yang dimuat didalamnya kepada ahli warisnya atau orang yang mendapat hak atas akta otentik tersebut. Akta dibawah tangan diakui

\footnotetext{
${ }^{4}$ Liliana Tedjosaputro, 'Kajian Hukum Pemberian Kuasa Sebagai Perbuatan Hukum Sepihak Dalam Surat Kuasa Membebankan Hak Tanggungan’ (2016) 13 Jurnal Spektrum Hukumol.[165].

5 Try Widiyono, Aspek Hukum Operasional Transaksi Produk Perbankan di Indonesia: simpanan, jasa, kredit (Ghalia Indonesia 2006).[50].

${ }^{6}$ Dadang Sungkar, 'Akta Otentik dan Akta Dibawah Tangan' (2014) <https://www. legalakses.com/akta-otentik-dan-akta-di-bawah-tangan/>, accessed 5 November 2019.
} 
dalam Pasal 1875 BW. Berlaku pula ketentuan pada Pasal 1871 BW untuk akta dibawah tangan tersebut. Jenis surat kuasa dapat dibedakan pula berdasarkan pelimpahan atau pengalihan kuasa yang diberikan (substitusi).

Surat Kuasa Jual tidak diatur secara jelas dan tegas dalam undang-undang sebagai lembaga jaminan untuk pembebanan atau pengikatan objek jaminan. Dalam Pasal 1795 BW diatur mengenai pemberian kuasa secara umum dan pemberian kuasa secara khusus. Pada dasarnya dalam pemberian kuasa jual ini pemberi kuasa memberikan kewenangan kepada penerima kuasa untuk mewakili dirinya karena pemberi kuasa tidak dapat hadir di hadapan PPAT untuk mengalihkan hak atas tanahnya, sehingga lahirnya kuasa jual seharusnya hanya disebabkan pemberi kuasa yang tidak dapat hadir secara langsung dihadapan PPAT untuk menandatangani akta peralihan hak atas tanahnya, bukan sebagai kuasa untuk menjaminkan atau membebani atau mengikat hak atas tanah atas utangnya sebagai debitor. ${ }^{7}$ Namun faktanya surat kuasa jual telah menjadi alat bagi bank guna menjamin pelunasan utang debitor apabila debitor wanprestasi. Berkaitan dengan pelunasan utang ini dijelaskan dalam Pasal 1131 BW yang menegaskan bahwa segala kebendaan debitor, baik yang bergerak maupun yang tidak bergerak, baik yang sudah ada maupun yang baru akan ada dikemudian hari, menjadi tanggungan untuk perikatannya perseorangan.

Dalam Surat Kuasa jual ini tidak diperlukan janji lagi tetapi secara otomatis ketika debitor wanprestasi atau cidera janji maka objek jaminannya kemudian dapat dijual oleh pemegang jaminan dalam hal ini adalah pihak bank melalui di bawah tangan atas kekuasaan sendiri berdasarkan kuasa jual yang diterima. Dengan demikian bank menjual atas kekuasaan sendiri ini tanpa memerlukan fiat eksekusi, kuasa jual pada prinsipnya sama dengan Hak Tanggungan yaitu guna mengeksekusi objek jaminan. Eksekusi objek jaminan dengan surat kuasa jual ini kemudian dilengkapi dengan pernyataan sukarela oleh debitor, yang mana

${ }^{7}$ Asriadi Zainuddin, Op.Cit.[308]. 
sebelum dilaksanakan eksekusi menggunakan surat kuasa jual pihak bank lebih dulu meminta debitor memberikan pernyataan kesukarelaannya tersebut agar saat dieksekusi tidak terjadi perlawanan oleh debitor. ${ }^{8}$

\section{Hak Tanggungan}

Berdasarkan amanat Pasal 51 Undang-Undang Nomor 5 Tahun 1960 Tentang Peraturan Dasar Pokok-Pokok Agraria yang selanjutnya akan disebut UUPA, melahirkan Hak Tanggungan yang sesuai dengan Pasal 1 angka 1 UUHT, adalah hak jaminan yang dibebankan pada hak atas tanah, termasuk atau tidak termasuk benda-benda lain yang menjadi kesatuan dengan tanah tersebut, guna pelunasan tertentu, yang menjadikan kreditor tertentu memiliki kedudukan yang diutamakan dibandingkan dengan kreditor lainnya. Pada dasarnya Hak Tanggungan merupakan hak yang eksistensinya lahir akibat perjanjian yang diadakan oleh para pihak. Perjanjian jaminan yang melahirkan Hak Tanggungan dibuat oleh para pihak dengan tujuan untuk melengkapi perjanjian pokok berupa utang piutang atau perjanjian kredit, karena perjanjian jaminannya berkaitan dengan benda tidak bergerak dalam hal ini tanah, maka sesuai dengan undangundang bentuk pengikatannya harus dengan Hak Tanggungan. ${ }^{9}$ Perjanjian jaminan ini masuk kategori perjanjian kebendaan dan suatu perjanjian kebendaan harus memenuhi beberapa ciri-ciri, yaitu:

1. Hak tanggungan merupakan hak kebendaan;

2. Perjanjian pada hak tanggungan merupakan perjanjian yang bersifat accesoir.

3. Sesuai Pasal 2 UUHT diketahui bahwa hak tanggungan tidak dapat dibagi-bagi;

4. Pada Pasal 3 ayat (1) UUHT, dinyatakan bahwa hak tanggungan guna menjamin utang yang telah ada atau yang telah diperjanjikan dengan jumlah tertentu atau jumlah yang saat eksekusi hak tanggungan diajukan dapat ditentukan dengan berdasar pada perjanjian utang-piutang atau perjanjian lain yang menimbulkan utang-piutang tersebut;

5. Hak tanggungan dapat diberikan pada utang yang berasal dari sebuah hubungan hukum atas satu utang atau lebih yang asalnya dari beberapa hubungan hukum;

\footnotetext{
8 ibid.[311].

${ }^{9}$ Asriadi Zainudin, Loc.Cit.[315].
} 
6. Hak tanggungan hanya dapat dibebankan pada hak atas tanah sesuai dengan ketentuan pada Pasal 4 ayat (1) UUHT;

7. Isi dari hak tanggungan ialah hak untuk melunasi utang dari hasil penjualan benda jaminan, yang didalamnya tidak terdapat hak bagi kreditor untuk memiliki benda jaminan;

8. Dalam hak tanggungan terdapat asas spesialitas yang diatur dalam Pasal 11 ayat (1) huruf e UUHT dan Pasal 13 ayat (1) UUHT;

9. Hak tanggungan bertujuan untuk memberikan kemudahan dan kepastian dalam melaksanakan eksekusi, Pasal 6, 14 ayat (1),(2),(3), dan Pasal 20 UUHT.

Objek dari Hak tanggungan meliputi hak milik, hak guna usaha, hak guna bangunan, hak pakai atas tanah negara, hak pakai atas tanah hak milik, bangunan rumah susun dan hak milik satuan rumah susun yang berdiri diatas tanah hak milik, hak guna bangunan atau hak pakai yang diberikan oleh negara, hak lama, hak atas tanah yang berasal dari konversi hak lama yang telah memenuhi syarat untuk didaftarkan akan tetapi belum dilakukan pendaftaran. Pada hak pakai atas tanah negara dapat dijadikan objek hak tanggungan apabila telah didaftar dan dinyatakan dapat dipindah tangankan. ${ }^{10}$

Asas lain yang terdapat dalam Hak Tanggungan adalah asas pemisahan horisontal, dimana bangunan, tanaman, dan benda-benda diatas tanah yang merupakan satu kesatuan dengan tanah tidaklah merupakan bagian dari tanah tersebut, sehingga perbuatan hukum seperti jual-beli dan pembebanan jaminan tidak meliputi benda-benda yang ada diatas tanah tersebut. ${ }^{11}$ Asas ini lahir dari Pasal 51 UUPA yang merupakan awal dari lahirnya Hak Tanggungan, UUPA sendiri menganut asas hukum adat. ${ }^{12}$ Lain halnya dengan asas accessi atau yang juga biasa disebut dengan asas perlekatan yang dianut oleh BW. Berdasarkan Pasal 1165 BW, dapat disimpulkan bahwa benda-benda diatas tanah, bangunan, tanaman merupakan satu kesatuan dengan tanah, sehingga dalam melaksanakan perbuatan hukum seperti jual-beli dan pembebanan jaminan tidak perlu ada pernyataan tegas atasnya. Namun penerapan asas

${ }^{10}$ Trisadini Prastinah Ustani dan Leonora Bakarbessy, Hukum Jaminan (Revka Petra Media 2016).[95].

11 ibid.[97].

12 ibid. 
pemisahan horisontal tidaklah mutlak, sebab harus disesuaikan dengan perkembangan dan kebutuhan masyarakat.

Pemberian hak tanggungan didahului dengan janji guna memberikan Hak Tanggungan sebagai jaminan untuk pelunasan utang tertentu, hal ini kemudian dituangkan didalam perjanjian utang-piutang. Hak Tanggungan mempunyai kekuatan eksekutorial sebab hak tanggungan merupakan amanat dari undangundang. Hak tanggungan harus didaftarkan dengan tujuan untuk mendapatkan kepastian hukum dan perlindungan hukum bagi pemegang Hak Tanggungan dan dengan didaftarkannya maka pemegang Hak Tanggungan akan memperoleh sertipikat Hak Tanggungan yang mempunyai kekuatan eksekutorial sebagaimana yang telah disebut di atas.

\section{Praktik Penggunaan Surat Kuasa Jual dan Memasarkan Sukarela}

Dalam praktik perbankan di Indonesia, pemberian kredit umunya selalu diikuti penyediaan jaminan oleh pemohon kredit, sehingga pemohon kredit yang tidak bisa memberikan jaminan sulit untuk memperoleh kredit dari bank. Prinsipnya setiap orang bertanggung jawab mana dengan menyediakan kekayaan baik benda bergerak maupun tidak bergerak untuk dijual apabila wanprestasi cidera janji dan agar prinsip ini dapat dilaksanakan, menurut hukum yang dituangkan dalam bentuk perjanjian.

Jaminan dalam pemberian kredit pada hakikatnya berguna untuk kepastian debitur dalam pelunasan utang, apabila debitur cidera janji atau dinyatakan pailit. Oleh karena itu dengan adanya jaminan pemberian kredit tersebut maka akan memberikan jaminan perlindungan bagi keamanan dan kepastian hukum dari kreditur atau pihak bank bahwa kreditnya akan tetap kembali walaupun debitur wanprestasi, yakni dengan cara mengeksekusi objek jaminan kredit bank yang bersangkutan. Untuk memperkecil risiko dalam memberikan kredit bank harus mempertimbangkan hal yang terkait dengan itikad baik dalam kemampuan membayar nasabah untuk melunasi kembali pinjaman beserta bunga. Pada prinsipnya bank tidak akan berani atau tidak mau mengambil risiko dengan 
menyalurkan kredit tanpa adanya jaminan kebendaan. Jaminan kredit atau pembiayaan merupakan keyakinan atas kemampuan dan kesanggupan nasabah untuk melunasi kewajibannya sesuai dengan yang diperjanjikan, dengan demikian jaminan itu pada dasarnya bukanlah satu-satunya agunan tetapi meliputi watak, kemampuan, modal, kondisi ekonomi maupun prospek usaha dari calon nasabah. Jaminan berperan penting dalam memberikan hak dan kekuasaan bagi bank selaku kreditur untuk mendapatkan pelunasan piutangnya, apabila peminjam tidak dapat membayar kembali utangnya pada waktu yang ditentukan / ditetapkan dalam perjanjian. Hal ini dikarenakan tidak semua nasabah yang mendapatkan kredit pinjaman dari debitor dapat menggunakan dananya dengan baik serta benar.

Dalam aktivitas pemberian kredit oleh perbankan penggunaan surat kuasa jual dan memasarkan sukarela dianggap sebagai salah satu elemen yang penting saat bank akan memberikan fasilitas kredit. Meskipun dalam perjanjian utang piutangnya sudah diikat atau dijamin dengan Akta Pemberian Hak Tanggungan atau yang biasa disebut APHT yang didalamnya telah mengatur janji - janji sebagaimana yang tertuang dalam Pasal 11 ayat (2) UUHT. Substansi kuasa jual adalah pemberian kuasa berupa kewenangan kepada penerima kuasa untuk bertindak atas nama pemberi kuasa untuk melakukan perbuatan hukum jual beli tanah, yang mana pemegang hak atas tanah tersebut adalah si pemberi kuasa. Didalam surat kuasa jual juga harus dicantumkan secara jelas dan tegas serta terinci tentang objek dari kuasa termaksud, seperti, luas tanah; nomor sertipikat hak atas tanah; uraian surat ukur/gambar situasi; batas-batas tanah, sebab hal ini berkaitan langsung dengan proses peralihan haknya pada saat akan dilakukan eksekusi atau penjualan objek jaminan. Hal ini dimaksudkan agar kreditor tidak kesulitan dalam melakukan penjualan objek jaminan.

Kewenangan dalam sebuah kuasa jual merupakan kewenangan untuk melakukan tindakan hukum atau perbuatan hukum berupa pengalihan hak atas tanah milik pemberi kuasa oleh penerima kuasa atau mengambil tindakan pemilikan seperti menjual baik terhadap diri sendiri maupun kepada orang lain/ pihak lain. Kewenangan ini diatur dan diakui oleh hukum, tetapi bukan berarti 
bahwa penerima kuasa mempunyai kewenangan mutlak untuk melakukan atau tidak melakukan sesuatu, karena si penerima kuasa diberi batasan-batasan yang diatur oleh hukum. Bank selalu meminta untuk dibuatkan surat kuasa jual dari debitor karena kuasa jual dianggap sangat efektif, lebih mudah dan biayanya murah dibandingkan dengan Hak tanggungan apabila objek jaminan akan dijual pada saat debitor wanprestasi/cidera janji.

Namun Hak Tanggungan dan Kuasa menjual tidak boleh atau tidak dapat diberlakukan secara bersamaan. Dengan demikian, kreditor hanya memilih apakah Hak Tanggungan atau Kuasa Menjual yang akan difungsikan untuk menjual objek jaminan apabila debitor wanprestasi atau cidera janji. Bank lebih memprioritaskan penggunaan surat kuasa jual, hal ini dikemukakan oleh Notaris/PPAT Gunawan Budiarto bahwa bank menggunakan kuasa menjual untuk menghindari biaya lelang sebesar $10 \%$ (sepuluh persen). Menurut beliau perjanjian utang piutang yang dibuat berdampingan dengan kuasa menjual, maka kuasa menjual tersebut sifatnya accessoir dengan perjanjian utang piutangnya yang artinya dapat dilaksanakan ataupun berakhir sebagaimana yang dimaksud dalam perjanjian utang piutangnya.

Surat kuasa jual dan memasarkan sukarela oleh bank merupakan bentuk surat kuasa yang sifatnya mutlak. Hal ini dibuktikan dengan adanya kalimat "Surat Kuasa ini yang tidak dapat ditarik kembali, dicabut dan/atau tidak akan berakhir dikarenakan sebab-sebab yang tercantum dalam ketentuan Pasal 1813 s/d 1815 BW." Objek perjanjian dari surat kuasa jual ialah tanah dan bangunan yang ada diatasnya bila ada.

\section{Pembatasan Kewenangan Dalam Penggunaan Surat Kuasa Jual}

\section{Konsep pemberian kuasa}

Ketika orang tidak dapat melaksanakan suatu perbuatan yang menyangkup kepentingan hukumnya karena suatu alasan tertentu, maka orang lain dapat mewakilikepentinganhukum tersebutmelaluidengan pemberiankuasa.Pemberian kuasa ini pada umumnya dilaksanakan dengan bentuk surat khusus. Pemberian 
kuasa adalah suatu persetujuan dimana seseorang memberikan kekuasaan kepada orang lain yang menerima kuasa tersebut, guna menyelenggarakan suatu urusan untuk dan atas nama pemberi kuasanya, hal ini dijelaskan dalam Pasal 1792 BW. Pemberian kuasa dapat dilakukan secara khusus atau dapat dilakukan secara umum maupun secara lisan. Pemberian kuasa khusus maksudnya pemberian kuasa yang dilakukan oleh pemberi kuasa kepada penerima yang isi dari kuasanya hanya mengenai kepentingan tertentu saja, lain halnya dengan pemberian kuasa secara umum yaitu pemberian kuasa oleh pemberi kuasa kepada penerima kuasa yang isi dari kuasanya bersifat umum atau meliputi segala kepentingan si pemberi kuasa. Dalam menjalankan kewajiban yang ditentukan daam surat kuasa, ada kalanya penerima kuasa berhalangan karena suatu sebab yang mendesak, dalam surat kuasa juga dikenal dengan adanya hak substitusi yaitu mengalihkan sebagian maupun seluruhnya kuasa diberikan kepada si penerima kuasa pada pihak ketiga

Pemberian kuasa juga suatu perjanjian, sebagai perjanjian yang terdiri dari dua pihak yaitu pemberi kuasa dan penerima kuasa. Hubungan dari kedua pihak tersebut mempunyai sifat yang konsensual yang berarti kedua belah pihak mempunyai kata sepakat atas isi dari pemberian kuasa tersebut, dan juga mempunyai sifat begaransi yang mempunyai arti tanggung jawab pemberi kuasa hanya sebatas kekuasaannya yang diberikan kepada si penerima kuasa, segala tindakan penerima kuasa di luar kekuasaan yang diberikan pemberi kuasa kepadanya merupakan tanggung jawab penerima kuasa sendiri. Pada umumnya pemberian suatu kuasa dapat disamakan seperti pemberian penawaran yang mengikat, apabila suatu penawaran telah diterima, maka terjadilah pengikatan antara pihak yang memberikan dengan pihak yang menerima walaupun nantinya sebelum perjanjian dilaksanakan.

\section{Terjadinya Penerima Kuasa Menerima Kuasa}

Bentuk surat kuasa dapat berupa akta otentik dalam tulisan tangan, dalam bentuk sepucuk surat dapat pula secara lisan seperti yang diatur dalam Pasal 1793 BW. Berdasarkan ketentuan Pasal 1792 BW dan 1793 BW tersebut 
dapat disimpulkan bahwa dalam menerima kuasa, penerima kuasa tidak wajib menandatangani kuasa tersebut sebagai bentuk penerimaan kuasa. Dengan kata penerimaan kuasa terjadi saat kuasa tersebut dilaksanakan oleh penerima kuasanya. Namun dalam praktek di pengadilan sebagian hakim berpendapat bahwa surat kuasa harus ditanda tangani oleh kedua belah pihak, baik pemberi kuasa maupun penerima kuasa. ${ }^{13}$

\section{Hak dan kewajiban pemberi kuasa dan penerima kuasa}

Hubungan hukum yang terjadi antara pemberi kuasa dan penerima akan menyebabkan suatu hukum. Akibat munculnya hak dan kewajiban dari ke dua pihak. Kewajiban penerima kuasa adalah sebagai berikut :

1. Melaksanakan kuasanya dan bertanggung jawab atas segala biaya, kerugian dan bunga yang akibat dari dilaksanakan kuasa tersebut;

2. Menyelesaikan urusan yang telah mulai dikerjakan pada waktu pemberi kuasa meninggal dan dapat menimbulkan kerugian jika tidak segera diselesaikan;

3. Bertanggung jawab segala perbuatan yang akan dilakukan dengan sengaja dan kelalaian-kelalaian yang dalam menjalankan kuasanya;

4. Memberikan laporan kepada pemberi kuasa tentang apa yang dilakukan, serta memberi perhitungan segala sesuatu yang diterimanya;

5. Bertanggung jawab atas orang lain yang ditunjuknya sebagai pengganti dalam melaksanakan kuasanya.

Hak dari penerima kuasa yaitu menerima jasa dari pemberi kuasa

Kewajiban dari pemberi kuasa:

1. Memenuhi perjanjian yang telah dibuat antara penerima kuasa dengan pemberi kuasa;

2. Mengembalikan biaya yang telah dikeluarkan dari penerima kuasa;

3. Membayar biaya kepada penerima kuasa;

4. Memberikan ganti rugi kepada penerima kuasa atas kerugian sewaktu menjalankan kuasanya;

Hak pemberi kuasa ialah menerima hasil atau jasa dari penerima kuasa.

${ }_{13}$ Amier Hakim, 'Keabsahan Surat Kuasa', (2011) <hukumonline.com> accessed 10 November 2019. 


\section{Batasan Surat Kuasa}

Batasan dalam surat kuasa mengandung 4 unsur penting, yaitu :

a. Adanya persetujuan;

b. Adanya para pihak, yaitu pemberi kuasa dan penerima kuasa;

c. Bertindak untuk dan atas nama pemberi kuasa;

d. Untuk menyelenggarakan suatu urusan.

\section{Berakhirnya Surat Kuasa}

Surat kuasa dapat berakhir demi hukum sesuai dengan aturan dalam suatu undang-undang. Dalam Pasal 1813 BW dinyatakan bahwa pemberian kuasa dapat berakhir, karena ditariknya kembali kuasanya oleh pemberi kuasa, pemberitahuan penghentian kuasanya oleh si penerima kuasa, meninggalnya, pengampuannya, pailitnya sang pemberi kuasa atau penerima kuasanya, pemberi kuasanya kawin dengan penerima kuasanya. Maksud dari pemberi kuasanya kawin dengan penerima kuasa, apabila yang memberi kuasa adalah seorang perempuan kemudian ia melakukan perkawinan, maka ia dianggap sepenuhnya cakap menurut hukum. ${ }^{14}$ Selain itu dijelaskan pula dalam Pasal 1816 BW bahwa apabila diangkat seorang kuasa baru untuk menjalanka suatu urusan yang sama, menyebabkan ditariknya kembali kekuasaan yang pertama, terhitung sejak diberitahukannya penerima kuasa baru. Mengenai ditarik kembalinya suatu kuasa oleh pemberi kuasanya, menurut Pasal 1814 BW dapat dilakukan sewaktu-waktu. M. Yahya Harahap berpendapat meskipun surat kuasa tersebut ditanda tangani oleh kedua belah pihak, apabila sang pemberi kuasa mencabut kuasanya secara sepihak tidak berarti perbuatannya bertentangan, sebab seperti yang telah dijelaskan diatas bahwa pada Pasal 1813 BW, pemberi kuasa dapat menarik kembali kuasanya.

\section{Surat Kuasa Jual yang Dibuat Bank}

Surat kuasa jual oleh bank pada umumnya berisi, mengenai pemberian kuasa oleh debitor kepada bank sebagai penerima kuasa, untuk melakukan transaksi

${ }^{14}$ Subekti, Aneka Perjanjian (Citra Aditya Bakti 1995).[151]. 
jual beli, termasuk perbuatan-perbuatan yang dibutuhkan dalam melakukan transaksi jual beli. Surat kuasa jual merupakan surat kuasa yang telah disiapkan oleh bank melalui notaris, disetiap pemberian fasilitas kredit kepada nasabah debitor. Surat kuasa menjual juga merupakan wujud dari pemberian kekuasaan dari pihak debitur kepada pihak bank untuk melaksanakan penjualan jika debitur cedera janji. Surat kuasa menjual termasuk dalam kuasa khusus, kuasa khusus adalah pemberian kuasa mengenai hanya satu kepentingan tertentu atau lebih. Untuk melakukan perbuatan tertentu diperlukan pemberian kuasa khusus yang menyebutkan perbuatan yang harus dilakukan misalnya menjual atas jaminan yang diberikan kepada pihak bank

Dibuatnya surat kuasa jual ini dimotifasi oleh keinginan bank untuk mempermudah kegiatan eksekusi objek jaminan, apabila sewaktu waktu debitor wanprestasi. Dalam pemberian fasilitas kredit oleh bank, surat kuasa jual merupakan unsur yang sangat penting. Bagi bank surat kuasa jual selain memberi kemudahan dalam melaksanakan eksekusi objek jaminan juga memberi jaminan.

Dalam melaksanakan eksekusi menggunakan surat kuasa jual bank sebagai penerima kuasa tidak memiliki wewenang lebih dari apa yang dikuasakan kepadanya, sehingga bank hanya dapat bertindak untuk dan atas nama debitor. Pada surat kuasa jual dan memasarkan sukarela dinyatakan bahwa bank sebagai kreditor diberi kuasa untuk menjual dengan cara apapun dan kepada siapapun objek jaminannya, memasang iklan, menemui semua pihak yang berpotensi menjadi pembeli, menemui dan/atau menghadap pejabat yang berwenang sepanjang berkaitan dengan isi surat kuasanya, menetapkan harga, mengurus, surat-surat ijin ke instansi yang berwenang, membayar segala biaya-biaya yang timbul dengan sumber dana yang menjadi kewajiban/tanggungan dari pemberi kuasa dalam hal ini nasabah sebagai debitor, menerima uang tanda jadi, menerima uang pembayaran pelunasan, menandatangani tanda penerimaan atau kwitansinya, menandatangani Perjanjian Pengikatan Jual Beli dan/atau Akta Jual Beli, serta perbuatan-perbuatan lain yang dipandang perlu tanpa dikecualikan. Meski mendapat kuasa yang begitu luas, surat kuasa jual tidak memiliki kekuatan 
mengikat, sebab surat kuasa jual tidak dapat didaftar, bukan juga merupakan objek pendaftaran tanah. ${ }^{15}$ Apabila terjadi persoalan hukum atau timbul gugatan dikemudian hari oleh pihak ketiga bank sebagai kreditor tidak memiliki hak preferen. ${ }^{16}$ Contoh persoalan hukum yang dapat timbul adalah ketika objek jaminan bukan milik debitor langsung atau sertipikat hak atas tanahnya atas nama orang lain, jika terjadi keberatan dari yang bersangkutan bisa saja mengajukan gugatan mengenai penjualan yang dilakukan. ${ }^{17}$

Grosse akta yang memiliki kekuatan eksekutorial berdasarkan pengertian dalam Undang-Undang Nomor 2 Tahun 2014 tentang Jabatan Notaris yang selanjutnya akan disebut UU No. 2 Tahun 2014, adalah salinan akta untuk pengakuan utang dengan kepala akta “Demi Keadilan Berdasarkan Ketuhanan Yang Maha esa". Dari Pasal 224 HIR / Pasal 258 RBg diperoleh kesimpulan bahwa grosse akta terdiri dari grosse akta pengakuan utang dan grosse akta hipotik, mengenai hipotik terdapat hipotik atas tanah dan hipotik atas kapal. Sejak lahirnya UUPA maka hipotik atas tanah tersebut digantikan dengan hak tanggungan. Penggunaan surat kuasa menjual jaminan sebagai pengamanan dapat mewakili kepentingan bank sebagai kreditur apabila debitur cidera janji, hal ini karena kuasa menjual pada dasarnya adalah untuk menjamin pelunasan utang debitur, dalam pengertian kreditur sangat berkepentingan untuk mengambil pelunasan hutang tersebut demi untuk memperkecil atau mengurangi kerugian bahkan mencegah kerugian dalam menyalurkan kredit, dan memberikan kepastian hukum dan perlindungan hukum bagi keamanan kreditur. Kemudian kuasa menjual akan berlaku atau berfungsi secara efektif apabila berdiri dalam artian bahwa tidak ada bentuk pengikatan atau pembebanan lain seperti hak tanggungan, kreditur tidak dapat serta merta menjual objek jaminan dengan hanya berdasar pada kuasa menjual tetapi kreditur masih meminta pernyataan penyerahan sukarela dari debitur sebelum menjual objek jaminannya.

15 Riny Dwiyanti Manaroinsong, Anwar Borahima, dan Nurfaidah Said, 'Kedudukan Hukum Surat Kuasa Menjual Terhadap Objek Jaminan yang Dibebani Hak Tanggungan', Jurnal Pasca Unhas.[8].

16 ibid.

17 ibid.[12]. 
Dalam kaitannya dengan penggunaan fungsi kuasa jual ini, penulis berpendat pad dasarnya fungsi kuasa menjual bagi debitur adalah untuk menjamin pelunsn hutangya kepada kreditur. Sedangka bagi kreditur adalah sebagai alat untuk menjual atau mengalihkan kepemilikan atas objek jaminan untuk mendapatkan pelunasan hutang dari debitur. Namun dalam praktek penjualan objek jaminan apabila debitur wanprestasi/ ingkar janji dengan syarat apabila terjadi kelebihhan harga dari objek jaminan maka kelebihan harga akan dikembalikan kepada debitur. Funsgi kuasa menjual ini menjadi tidak berarti apabila kuasa menjual ini bersama-sama disandingkan dengan hak tanggungan. Apabila debitur wanprestasi dan objek jaminan akan diesksekusi maka secara huum digunakan adalah Sertifikat. Jika para pihak sepakat dan setuju untuk menjual objek jaminan itu secara di bawah tangan dengan ketentuan asal mencapai harga yang tertinggi dan menguntungkan kedua belah pihak.

\section{Analisis Berdasarkan Peraturan Perundang-Undangan}

\section{Analisis Penggunaan Surat Kuasa Jual Bedasarkan BW}

Konsep Surat Kuasa Jual dan Memasarkan Sukarela pada dasarnya adalah bentuk pelimpahan kuasa oleh nasabah bank selaku debitor kepada bank selaku kreditor untuk melaksanakan urusannya berkaitan dengan penjualan dan pemasaran agunan. Sesuai dengan Pasal 1797BW, bank selaku penerima kuasa tidak diperbolehkan melakukan tindakan melampaui apa yang telah dikuasakan kepadanya saja. Surat kuasa jual ini berbentuk surat kuasa khusus, dalam Pasal 1796 BW dijelaskan bahwa untuk memindahtangankan barang, meletakkan hipotek, membuat suatu perdamaian, ataupun melakukan tindakan yang hanya dapat dilakukan oleh pemiliknya, harus dibuat surat kuasa secara khusus dengan kata-kata yang tegas.

Pemberian kuasa dilakukan karena pemberi kuasa tidak dapat melaksanakan perbuatan hukumnya sendiri, sehingga ia memberikan kuasanya kepada penerima kuasa. Kehadiran penerima kuasa ini memberikan konsekuensi seakan-akan pihak pemberi kuasa tersebut hadir untuk melaksanakan perbuatan 
hukumnya sendiri. Sehingga yang bertanggung gugat atas setiap perbuatan hukum yang dilakukan penerima kuasa adalah sang pemberi kuasa. Namun, tanggung gugat tersebut sebatas pada apa yang dikuasakan kepada sang penerima kuasanya saja. Apabila sang penerima kuasa melakukan perbuatan hukum diluar dari kewenangan yang diberikan kepadanya maka penerima kuasa tersebut harus bertanggung gugat sendiri.

\section{Analisis Penggunaan Surat Kuasa Jual Bedasarkan SK MENDAGRI No. 14}

\section{Tahun 1982}

Dalam praktiknya surat kuasa jual dan memasarkan sukarela oleh bank kebanyakan berbentuk surat kuasa mutlak. Hal ini dibuktikan dengan klausula tidak dapat ditarik kembali kuasanya. Berkaitan dengan bentuk surat kuasa jual ini, bertentangan dengan SK MENDAGRI No.14 Tahun 1982. Didalam SK MENDAGRI No. 14 Tahun 1982 dinyatakan bahwa penggunaan surat kuasa mutlak yang berkaitan dengan pemindahan hak atas tanah dilarang. Larangan ini berlaku pula bagi pejabat yang berwenang dalam pembuatan akta dari surat kuasa tersebut, dimana para pejabat berwenang dilarang untuk membuat/ menguatkan surat kuasa mutlak berkaitan dengan pemindahan hak atas tanah, dan melayani penyelesaian status hak atas tanah yang menggunakan surat kuasa mutlak sebagai dasar pembuktian pemindahan hak atas tanahnya. Melalui analisis ini maka surat kuasa jual dan memasarkan sukarela yang dibuat secara mutlak akan batal demi hukum.

Adapun yang dimaksud dengan kuasa mutlak di sini tercantum dalam SK MENDAGRI No. 14 Tahun 1982 yang menyatakan bahwa kuasa mutlak yang dimaksud di sini adalah kuasa yang tidak dapat dicabut kembali. Di sinilah merupakan wujud dari adanya asas kebebasan dalam ikatan pemberian kuasa. Mengapa klausal itu merupakan kebebasan dalam membuat perjanjian, hal ini karena kausa mutlak itu sendiri tidak diatur secara khusus dalam peraturan hukum Indonesia, tetapi timbul dan adanya kebebasan dalam membuat perjanjian. 


\section{Analisis Penggunaan Surat Kuasa Jual Bedasarkan POJK No. 1 Tahun 2013}

Pembahasan mengenai surat kuasa dalam POJK No. 1 Tahun 2013 terletak pada Pasal 22 Ayat (3) huruf C, yang didalamnya menjelaskan bahwa dalam perjanjian baku dilarang adanya pernyataan pemberian kuasa dari konsumen dalam hal ini adalah nasabah selaku debitor, baik secara langsung maupun tidak langsung untuk melakukan segala tindakan sepihak atas barang yang diagunkan oleh konsumen kecuali tindakan sepihak tersebut berdasarkan perundangundangan. Ketentuan ini menegaskan bahwa bank sebagai pelaku usaha jasa keuangan tidak dapat melakukan tindakan sepihak atas benda yang diagunkan tadi, sehingga penggunaan surat kuasa jual dan memasarkan sukarela hanya bisa terjadi apabila tercapai kesepakatan untuk menjual agunan tersebut oleh nasabah selaku debitor.

Pengertian POJK No. 1 Tahun 2013 Pasal 22 Ayat (3) huruf C dapat diuraikan, bahwa pihak Bank selaku kreditur tidak bisa melakukan tindakan penjualan langsung atas benda yang diagunkan / dijaminkan kepada pihak bank oleh nasabah sebagai debitor melainkan terjadi penjualan jika sudah melalui kesepekatan untuk menjual agunan tersebut oleh nasabah selaku debitor.

\section{Analisis Penggunaan Surat Kuasa Jual Bedasarkan UU Hak Tanggungan}

Sesuai dengan ketentuan Pasal 15 ayat (5) UU Hak Tanggungan, batas waktu berlakunya surat kuasa membebankan hak tanggungan yang diberikan untuk menjadi beberapa jenis kredit tertentu dikecualikan Pasal 15 ayat (2) dan (3) dimana Pasal 1 peraturan menteri negara agraria / kepala badan pertanahan nasional Nomor 4 Tahun 1996 yang selanjutnya akan disebut PERMEN Agraria No. 4 Tahun 1996 tersebut menetapkan bahwa surat kuasa membebankan hak tanggungan (SKMHT) berlaku sampai berakhirnya masa berlakunya perjanjian pokok kredit.

Sesuai UU Hak Tanggungan, Fungsi dan tujuan dasar dari surat kuasa membebankan hak tanggungan (SKMHT) tidak boleh memuat kuasa untuk menjual, menyewakan objek. hak tanggungan atau memperpanjang hak atas 
tanah, melainkan hanya sebagai sarana pemberian kuasa untuk membuat Akta Pemberian Hak Tanggungan (APHT). dalam pasal 15 ayat (1) huruf a UU Hak Tanggungan disebutkan secara spesifik salah satu syarat untuk Surat Kuasa Membebankan Hal Tanggungan (SKMHT) adalah tindak memuat kuasa untuk melakukan perbuatan hukum lain daripada membebankan hak tanggungan.

Dalam PERMEN No. 4 Tahun 1996 mengenai penetapan batas waktu penggunaan surat kuasa membebankan hak tanggungan untuk menjamin pelunasan kredit-kredit tertentu pada Pasal 1 dissebutkan "Surat Kuasa Membebankan Hak Tanggungan yang diberikan untuk menjamin pelunasan jenis - jenis Kredit Usaha Kecil “.

Dari kalimat "Menjamin kredit tertentu" dalam undang-undang hak tanggungan nomor 4 tahun 1996 dan kalimat "menjamin pelunasan" dalam peraturan menteri negara agraria / Kepala pertanahan nasional nomor 4 tahun 1996 seolah menimbulkan penafsiran jaminan pelunasan terhadap kredit debitor jika suatu saat terjadi kredit bermasalah.

Penjabaran mengenai fungsi surat kuasa membebankan hak tanggungan (SKMHT) terkait jaminan kredit tertentu di atas menegaskan bahwa undangundang tidak memberikan aturan baru terkait pelunasan kredit dari suatu jaminan atau hak eksekutorial atas suatu jaminan di bank. Undang-undang hanya memberikan jembatan agar masyarkat tidak terbebani biaya yang terlalu besar pada saat mengajukan kredit di bank. Sehingga jika terjadi kredit bermasalah, pihak bank (kreditur) harus tetap melakukan upaya untuk hukum lanjutan terhadap Surat Kuasa Membebankan Hak Tanggungan (SKMHT) kredit tertentu tersebut agar memiliki kekuatan eksekutorial sesuai diatur undang-undang yang berlaku.

\section{Perlindungan Hukum}

1. Perlindungan Hukum Preventif;

2. Perlindungan hukum refresif;

3. Perlindungan Hukum Bagi Kreditur (Bank);

4. Perlindungan Hukum Debitur (Nasabah). 


\section{Kesimpulan}

Surat kuasa dapat dibuat secara akta otentik maupun akta dibawah tangan. akta dibawah tangan adalah dokumen yang dibuat oleh para pihak tanpa adanya keberadaan dan campur tangan dari pejabat umum serta peraturan perundangundangan tidak mengharuskannya Dalam kaitannya dengan surat kuasa maka yang berwenang dalam membuat akta otentiknya adalah notaris, lain halnya dengan Surat Kuasa Membebani Hak Tanggungan yang selanjutnya disebut SKMHT hanya dapat dibuat oleh Pejabat Pembuat Akta Tanah yang selanjutnya akan disebut PPAT. Pasal 1870 BW menyatakan bahwa akta otentik memberikan suatu bukti yang sempurna atas apa yang dimuat didalamnya kepada ahli warisnya atau orang yang mendapat hak atas akta otentik tersebut. Akta dibawah tangan diakui dalam Pasal 1875 BW. Berlaku pula ketentuan pada Pasal 1871 BW untuk akta dibawah tangan tersebut. Pembuktian dalam akta otentik terjamin atas kebenaran maupun kepastian tanggal, tanda tangan yang ada, identitas para pihak yang hadir, serta tempat dimana akta itu dibuat. Hal ini menyebabkan akta otentik memiliki kekhususan sebagai alat bukti, yaitu apabila dikemukakan di pengadilan maka tidak diperlukan adanya bukti lain, asalkan akta tersebut memenuhi persyaratan seperti yang disebutkan diatas. Berdasarkan Pasal 1869 BW, jika akta otentik tidak memenuhi persyaratan tersebut maka akta otentik tersebut berubah menjadi akta dibawah tangan apabila akta tersebut ditanda tangani oleh para pihak Surat kuasa jual dan memasarkan sukarela oleh bank merupakan bentuk surat kuasa yang sifatnya mutlak. Hal ini dibuktikan dengan adanya kalimat "Surat Kuasa ini yang tidak dapat ditarik kembali, dicabut dan/atau tidak akan berakhir dikarenakan sebab-sebab yang tercantum dalam ketentuan Pasal 1813 s/d 1815 BW." Objek perjanjian dari surat kuasa jual ialah tanah dan bangunan yang ada diatasnya bila ada.

Dalam menggunakan surat kuasa jual dan memasarkan sukarela, bank hanya memiliki kewenangan sesuai dengan apa yang disampaikan dalam surat kuasanya saja sesuai dengan Pasal 1797 BW. Selain itu dalam penggunaannya surat kuasa jual dan memasarkan sukarela karena sifatnya tidak boleh mutlak seperti 
yang dijelaskan pada SK MENDAGRI No. 14 Tahun 1982, maka apabila kuasanya dicabut oleh debitor maka kewenangan dalam melakukan kegaitan penjualan dan lainnya sesuai yang diperjanjikan tidak lagi berada padanya. Kewenangan melakukan eksekusi pada objek surat kuasa jual dan memasarkkan sukarela juga tidak dapat dilakukan secara sepihak melainkan harus melalui kesepakatan dengan debitor sebagai pemilik dari objek tersebut, apakah ia bersedia menjual objeknya atau tidak, hal ini dilakukan karena sesuai Pasal 22 Ayat (3) huruf c POJK No. 1 Tahun 2013, bank dilarang melakukan eksekusinya secara sepihak, sehingga kewenangan bank untuk menggunakan surat kuasaa jual dan memasarkan sukarela ada bila debitor sepakat memberikan kewenangan tersebut. Kaitannya dengan penggunaan surat kuasa jualdan memasarkan sukarela ini tidak dapat dicampur baurkan penggunaannya baik dengan Surat Kuasa Membebankan Hak Tanggungan (SKMHT), hal ini dijelaskan dalam UU Hak Tanggungan, bahwa didalam Surat Kuasa Membebankan Hak Tanggungan tidak boleh tercakup didalamnya kuasa untuk menjual ataupun menyewakan objeknya. Surat Kuasa Jual dan Memasarkan Sukarela tidak dapat digunakan bersama-sama dengan Hak Tanggungan. Sesuai dengan kedudukannya di mata hukum, maka apabila Hak Tanggungannya sudah diajukan eksekusi kewenangan penggunaan surat kuasa menjual dan memasarkan sukarela tidak dapat digunakan.

\section{Daftar Bacaan}

\section{Buku}

Peter Mahmud Marzuki, Penelitian Hukum Edisi Revisi (Kencana 2017).

S Salim H., Hukum Kontrak TeoriETeknik Penyusunan Kontrak (Sinar Grafika Jakarta 2009).

Subekti, Aneka Perjanjian (Citra Aditya Bakti 1995).

Trisadini Prasastinah dan Bakarbessy Leonora, Hukum Jaminan (Revka Petra Media 2014).

Try Widiyono, Aspek Hukum Operasional Transaksi Produk Perbankan di Indonesia: simpanan, jasa, kredit (Ghalia Indonesia 2006). 


\section{Jurnal}

Afrian Muhammad E, 'Kuasa Menjual sebagai Alternatif Penyelesaian Sengketa Kredit Macet di Kecamatan Sukajadi Kota Pekanbaru' (2016) JOM Fakultas Hukum.

R. D. Manaroinsong, Borahima A, dan Said N, 'Kedudukan Hukum Surat Kuasa Menjual Terhadap Objek Jaminan yang Dibebani dengan Hak Tanggungan' Jurnal Unhas.

Setyawan Alfis, 'Tinjauan Yuridis Penggunaan Surat Kuasa Jual Terhadap Penjualan Objek Hak Tanggungan Dalam Penyelesaian Kredit Macet' (2016) Jurnal Selat.

Tedjosaputro Liliana, 'Kajian Hukum Pemberian Kuasa Sebagai Perbuatan Hukum Sepihak Dalam Surat Kuasa Membebankan Hak Tanggungan’ (2016) Jurnal Spektrum Hukum.

Utami Putu Devi Yustisia, Diantha I Made Pasek, dan Sarjana I Made, 'Kedudukan Hukum Grosse Akta Pengakuan Hutang Notariil Dalam Pemberian Kredit Perbankan' (2018) Jurnal Ilmiah Prodi Hukum Kenotariatan.

Zainuddin Asriadi, 'Kedudukan Hukum Surat Kuasa Menjual terhadap Objek Jaminan yang Dibebani Hak Tanggungan', (2017) Jurnal Al-Himayah.

\section{Laman}

Admin, 'Mengenal Perjanjian Credit', (2019) <http://www.ercolaw.com/index.php?option $=$ com_content\&view $=$ article\&id=57:mengenal-perjanjian-kredit\&catid=25:the-project\&Itemid=50> accessed 19 Agustus 2019.

Dadang Sungkar, 'Akta Otentik dan Akta Di bawah Tangan', (2014) <https:// www.legalakses.com/akta-otentik-dan-akta-di-bawah-tangan/> accessed 5 November 2019.

Amier Hakim, 'Keabsahan Surat Kuasa', (2011) <https://www.hukumonline. com/berita/baca/hol19198/surat-kuasa-konsep-amanah-yang-seringsalah-kaprah/>, accessed 10 November 2019.

Disriani Latifah, 'Grosse Akta', (2014) <https://staff.blog.ui.ac.id/disriani.latifah/2014/10/08/grosse-akta/> accessed 10 Desember 2019.

\section{Perundang-undangan}

Undang-Undang Nomor 7 Tahun 1992 Tentang Perbankan. Lembaran Negara 
Nomor 32 Tahun 1992

Undang-Undang Nomor 4 Tahun 1996 Tentang Hak Tanggungan Atas Tanah Beserta Benda-Benda Yang Berkaitan Dengan Tanah. Lembaran Negara Nomor 42 Tahun 1996

Undang-Undang Nomor 10 Tahun 1998 Tentang Perubahan Atas Undang-Undang Nomor 7 Tahun 1992 Tentang Perbankan. Lembaran Negara Nomor 182 Tahun 1998

Undang-Undang Nomor 2 Tahun 2014 Tentang Jabatan Notaris. Tambahan Lembaran Negara Republik Indonesia Nomor 4432

Peraturan Menteri Negara Agraria / Kepala badan Pertanahan Nasional Nomor 4 Tahun 1996 Tentang Penetapan Batas Waktu Penggunaan Surat Kuasa Membebankan Hak Tanggungan Untuk Menjamin Pelunasan Kredit-Kredit Tertentu

Peraturan Otoritas Jasa Keuangan Nomor 1 Tahun 2013 Tentang Perlindungan Konsumen Sektor Jasa Keuangan. Lembaran Negara Republik Indonesia Tahun 2011 Nomor 111; Tambahan Lembaran Negara Republik Indonesia Nomor 5253

Instruksi Menteri Dalam Negeri Nomor 14 Tahun 1982 Tentang Larangan Penggunaan Kuasa Mutlak Sebagai Pemindahan Hak Atas Tanah

How to cite: Rizkia Aisyah Nur, 'Limitasi Penggunaan Surat Kuasa Penjualan dan Pemasaran Suka Rela Objek Jaminan Dalam Kredit Perbankan' (2021) Vol. 4 No. 1 Notaire. 
126 | Rizkia Aisyah: Limitasi Penggunaan Surat...

--Halaman ini sengaja dikosongkan-- 